\title{
Insights into the degradation capacities of Amycolatopsis tucumanensis DSM 45259 guided by microarray data
}

Bourguignon, Natalia; Bargiela, Rafael; Rojo, David; Chernikova, Tatyana; Lopez de Rodas, Sara A.; Garcia-Cantalejo, Jesus; Nather, Daniela J.; Golyshin, Peter; Barbas, Coral; Ferrero, Marcelo; Ferrer, Manuel

\section{World Journal of Microbiology and Biotechnology}

DOI:

$10.1007 / \mathrm{s} 11274-016-2163-8$

Published: 01/12/2016

Peer reviewed version

Cyswllt i'r cyhoeddiad / Link to publication

Dyfyniad o'r fersiwn a gyhoeddwyd / Citation for published version (APA):

Bourguignon, N., Bargiela, R., Rojo, D., Chernikova, T., Lopez de Rodas, S. A., Garcia-

Cantalejo, J., Nather, D. J., Golyshin, P., Barbas, C., Ferrero, M., \& Ferrer, M. (2016). Insights into the degradation capacities of Amycolatopsis tucumanensis DSM 45259 guided by microarray data. World Journal of Microbiology and Biotechnology, 32(201).

https://doi.org/10.1007/s11274-016-2163-8

\footnotetext{
Hawliau Cyffredinol / General rights

Copyright and moral rights for the publications made accessible in the public portal are retained by the authors and/or other copyright owners and it is a condition of accessing publications that users recognise and abide by the legal requirements associated with these rights.

- Users may download and print one copy of any publication from the public portal for the purpose of private study or research.

- You may not further distribute the material or use it for any profit-making activity or commercial gain

- You may freely distribute the URL identifying the publication in the public portal ?
}

Take down policy

If you believe that this document breaches copyright please contact us providing details, and we will remove access to the work immediately and investigate your claim. 
2 Insights into the degradation capacities of Amycolatopsis tucumanensis

$3 \quad$ DSM 45259 guided by microarray data

4 Natalia Bourguignon",\#, Rafael Bargiela ${ }^{2, \#}$, David Rojo ${ }^{3 \#}$, Tatyana N. Chernikova ${ }^{4}$, 5 Sara A López de Rodas $^{5}$, Jesús García-Cantalejo ${ }^{5}$, Daniela J Näther ${ }^{6}$, Peter N 6 Golyshin $^{4}$, Coral Barbas ${ }^{3}$, Marcela Ferrero ${ }^{1, \S}$, and Manuel Ferrer, , $^{*}$

71 Planta Piloto de Procesos Industriales Microbiológicos (PROIMI-CONICET), 8 Tucumán, Argentina.

92 Consejo Superior de Investigaciones Científicas (CSIC), Institute of Catalysis, 10 Madrid, Spain.

113 Centro de Metabolómica y Bioanálisis (CEMBIO), Facultad de Farmacia, 12 Universidad CEU San Pablo, Campus Monteprincipe, Boadilla del Monte, Madrid, 13 Spain.

144 School of Biological Sciences, Bangor University, Gwynedd LL57 2UW, UK.

155 Unidad de Genómica-Campus Moncloa, C.A.I. Genómica y Proteómica, Facultad 16 CC. Biológicas, Universidad Complutense de Madrid, Madrid, Spain.

176 Institute for Microbiology, Goethe University, Biocentre, Frankfurt, Germany.

*Correspondence

Manuel Ferrer mferrer@icp.csic.es 
$23{ }^{\#}$ These authors contributed equally to this work

$24 \quad{ }^{\S}$ These authors contributed equally to this work

25 Running title: Catabolome of A. tucumanensis

26 
27 Abstract The analysis of catabolic capacities of microorganisms is currently often achieved by cultivation approaches and by the analysis of genomic or metagenomic datasets. Recently, a microarray system designed from curated key aromatic catabolic gene families and key alkane degradation genes was designed. The collection of genes in the microarray can be exploited to indicate whether a given microbe or microbial community is likely to be functionally connected with certain degradative phenotypes, without previous knowledge of genome data. Herein, this microarray was applied to capture new insights into the catabolic capacities of copper-resistant actinomycete Amycolatopsis tucumanensis DSM 45259. The array data support the presumptive ability of the DSM 45259 strain to utilize single alkanes ( $n$-decane and $n$-tetradecane) and aromatics such as benzoate, phthalate and phenol as sole carbon sources, which was experimentally validated by cultivation and mass spectrometry. Interestingly, while in strain DSM 45259 alkB gene encoding an alkane hydroxylase is most likely highly similar to that found in other actinomycetes, the genes encoding benzoate 1,2dioxygenase, phthalate 4,5-dioxygenase and phenol hydroxylase were homologous to proteobacterial genes. This suggests that strain DSM 45259 contains catabolic genes distantly related to those found in other actinomycetes. Together, this study not only provided new insight into the catabolic abilities of strain DSM 45259, but also suggests that this strain contains genes uncommon within actinomycetes.

Keywords Alkanes · Amycolatopsis tucumanensis · aromatics · catabolome . degradation $\cdot$ microarray 


\section{Introduction}

Imagine the microbial communities responding to pollutants-intake and how variable this can be (Hazen et al. 2010; Kostka et al. 2011; Beazley et al. 2012; Guazzaroni et al. 2013; Gutierrez et al. 2013). The most obvious reaction will be their ability to react by degrading such pollutants to intermediates feeding the central metabolism (Liang et al. 2011; Lu et al. 2012; Mason et al. 2012; Kimes et al. 2013; Mason et al. 2014). There is great interest in identifying next-generation information that allows predicting the diversity of pollutants that each community and the microorganisms conforming it, can degrade and the catabolic genes implicated (Pérez-Pantoja et al. 2008; Pérez-Pantoja et al. 2012; Guazzaroni et al. 2013; Bargiela et al. 2015a). The analysis of catabolic capacities of microbial communities or single cultures begins by assessing gene contents, which are currently often achieved using genomic or metagenomic data (Guazzaroni et al. 2013; Bargiela et al. 2015a,b), followed by the analysis of the annotated genome or metagenome and a reference catabolic database as input information (Pérez-Pantoja et al. 2008; Pérez-Pantoja et al. 2012; Guazzaroni et al. 2013; Bargiela et al. 2015a,b). Further, catabolic network can be built, using as an input potential protein-coding gene sequences obtained by direct sequencing of DNA material and the web-based AromaDeg resource (Duarte et al. 2014; Bargiela et al. 2015a,b).

In case genome information is lacking, the identification of catabolic capacities required extensive experimental efforts, i.e. by producing microcosms in which the ability to degrade pollutants is investigated using labeled or not labeled compounds (Watanabe and Hamamura 2003; Pandey et al. 2008). With the aim of easing this process, a novel internally calibrated functional gene microarray system (the so-called catabolome array) was recently developed (Vilchez-Vargas et al. 2013). It contains optimally designed probes covering key aromatic catabolic gene families and key 
alkane degradation genes. This enables identifying molecular functions of identified genes in light of catabolic pathways by using DNA material, without the need of genome sequencing. The microarray contains 3605 probes $(50 \mathrm{mer})$ representing catabolic gene subfamilies encoding key activities in hydrocarbon degradation pathways, that included Rieske non-haem iron ring hydroxylating (di)oxygenases (RHDO), extradiol dioxygenases of the vicinal chelate superfamily (EXDOI), intradiol dioxygenases (INDO), soluble di-iron aromatic ring hydroxylating monooxygenases, ferredoxins of multicomponent aromatic degradation enzymes (FERRE), muconate cycloisomerases (MCIS), maleylacetate reductases (MACR), alkane hydroxylases of the integral membrane-bound monooxygenases (ALKB), cytochrome P450, CYP153 alkane hydroxylases (CYP153), benzoyl coenzyme A reductases (BCOAR), and benzylsuccinate synthases. Supplementary Table 1 provides information regarding accession numbers for sequences and taxonomic origin of catabolic genes associated to each of the probes. Briefly, most probes (circa 84\%) derived from genomes from cultivable bacteria of at least 182 different species, distributed among 70 genera that included Gordonia, Nocardioides, Rhodococcus, Prauserella, Mycobacterium, Nocardia, Dietzia, Corynebacterium, Frankia and Janibacter (Actinobacteria), Flavobacteria, Dokdonia, Polaribacter and Maribacter (Bacteroidetes), Geobacillus and Desulfitobacterium (Proteobacteria), Acinetobacter, Sphingomonas, Alcanivorax, Cycloclasticus, Pseudomonas, Legionella, Xanthomonas, Burkholderia, Oleiphilus, Xanthobacter, Thalassolituus, Acidisphaera, Photorhabdus, Bdellovibrio, Ruegeria, Rhodobacter, Ralstonia, Methylococcus, Bradyrhizobium, Hahella, Jannaschia, Polaromonas, Paraburkholderia, Paracoccus, Marinobacter, Sulfitobacter, Roseovarius, Oceanicola, Pseudooceanicola, Oceanicaulis, Loktanella, Maritimibacter, Parvularcula, Roseobacter, Acidiphilium, Psychrobacter, Bermanella, 
Stenotrophomonas, Blastochloris, Azoarcus, Magnetospirillum, Geobacter, Thauera,

Ensifer, Aromatoleum, Rhodopseudomonas, Syntrophobacter, Alkalilimnicola,

Desulfobacula, Parvibaculum, Sphingopyxis, Caulobacter, Erythrobacter and

Novosphingobium (Proteobacteria). Probes from species of Tetrahymena (Eukaryotia),

Neurospora (Ascomycota) and Methanopyrus (Euryarchaeota) are also included. Note that within bacterial species whose probes are included in the microarray, 30 belong to 10 genera (Gordonia, Nocardioides, Rhodococcus, Prauserella, Mycobacterium, Nocardia, Dietzia, Corynebacterium, Frankia and Janibacter) of the order Actinomycetales. Detailed information on all the probes on the array and the evolutionary relationships are reported elsewhere (Vilchez-Vargas et al. 2013).

In this work, we exploit the catabolome array (Vilchez-Vargas et al. 2013) to get new insights into the degrading capacities of A. tucumanensis strain DSM 45259, a copper-resistant actinobacterium isolated from polluted sediments (Albarracín et al. 2010a). Note that the threshold for considering a signal as a true positive in the array was set when hybridization occurred with a probe exhibiting $>80 \%$ sequence identity, where it can be assumed that the target DNA is derived from a gene encoding a member of the same subfamily as that for which the probe was designed (Vilchez-Vargas et al. 2013). This, together with the fact that the majority of the probes belong to bacteria, including actinomycetes (see above), suggest that catabolic genes of the actinomycete Amycolatopsis tucumanensis DSM 45259 will be detectable. Having said that, $A$. tucumanensis DSM 45259 was widely studied for its remarkable copper-resistance (Dávila Costa et al. 2011a,b; Dávila Costa et al. 2012). More recently, degradation of naphthalene and phenanthrene was found to occur in minimal medium when growing on glucose as co-substrate (Bourguignon et al. 2014). In the present study we provide evidences that A. tucumanensis DSM 45259 has also the capacity to use aliphatic and 
aromatic hydrocarbons such as $n$-decane, $n$-tetradecane, phthalate, benzoate and phenol as sole carbon sources. These abilities, predicted by the microarray, were further confirmed by cultivation tests and target mass spectrometry analysis. Although, such degradation capacities are common within other actinomycetes, the results suggest that strain DSM 45259 carries some catabolic genes distantly related to previous catabolic genes of other actinomycetes. In addition to that, because good agreement with the array-based predictions was observed after experimental validations, we suggest that the strategy herein described represents a promising strategy for disentangling contextsspecific catabolic phenotypes in any organism or microbial community, without the need of genome or metagenome sequencing.

\section{Materials and Methods}

\section{Chemicals and basic culture conditions}

136 All chemicals used were of the purest grade available and were purchased from Fluka137 Aldrich-Sigma Chemical Co. (St Louis, MO, USA). A. tucumanensis strain DSM 45259, a copper resistant strain, was used in this study (Albarracín et al. 2010a; Dávila Costa et al. 2012). Strain DSM 45259 was cultivated in Tryptic Soy Broth (TSB) medium (tryptein: $17 \mathrm{~g} \mathrm{~L}^{-1}$; soy peptone: $3 \mathrm{~g} \mathrm{~L}^{-1}$; NaCl: $5 \mathrm{~g} \mathrm{~L}^{-1} ; \mathrm{K}_{2} \mathrm{HPO}_{4}: 2.5 \mathrm{~g} \mathrm{~L}^{-1}$; 141 glucose: $2.5 \mathrm{~g} \mathrm{~L}^{-1}$; pH $7.3 \pm 0.2$ ) at $30{ }^{\circ} \mathrm{C}$ until late exponential growth phase. This 142 culture was used as pre-inoculum for a $30 \mathrm{ml}$ Minimal Media $(\mathrm{MM})$ broth $\left(\left(\mathrm{NH}_{4}\right)_{2} \mathrm{SO}_{4}\right.$ : $2 \mathrm{~g} \mathrm{~L}^{-1} ; \mathrm{K}_{2} \mathrm{HPO}_{4}: 0.5 \mathrm{~g} \mathrm{~L}^{-1} ; \mathrm{MgSO}_{4} .7 \mathrm{H}_{2} \mathrm{O}: 0.2 \mathrm{~g} \mathrm{~L}^{-1}$; $\mathrm{FeSO}_{4}: 0.01 \mathrm{~g} \mathrm{~L}^{-1}$; glucose: $1.25 \mathrm{~g}$ $\mathrm{L}^{-1}$; pH $7.0 \pm 0.2$ ) containing $0.2 \mathrm{mM}$ naphthalene (from a $25 \mathrm{mM}$ stock solution in acetone) and glucose $1.25 \mathrm{~g} \mathrm{~L}^{-1}$. Control culture without the addition of hydrocarbon was performed. Cultures were incubated at $30{ }^{\circ} \mathrm{C}$ and $180 \mathrm{rpm}$ for $96 \mathrm{~h}$, after which 
147 cultures were centrifuged $\left(8000 \mathrm{rpm} ; 10 \mathrm{~min} ; 4{ }^{\circ} \mathrm{C}\right)$ and cell pellets used for DNA 148 extraction.

\section{Catabolome microarray analysis}

150 The total DNA extraction was done by using cells harvested during late exponential 151 growth phase in cultures containing glucose and naphtalene as carbon sources, and the 152 hexadecyltrimethylammonium bromide (CTAB) method with some modifications 153 (Bailey et al. 1995). Briefly, harvested cells were re-suspended in $750 \mu \mathrm{L}$ lysozyme154 CTAB extraction solution $\left(8 \mathrm{mg} \mathrm{mL}^{-1}\right.$ lysozyme, $2 \%$ CTAB, $1.4 \mathrm{M} \mathrm{NaCl}, 20 \mathrm{mM}$ ethylenediaminetetraacetic acid (EDTA), $100 \mathrm{mM}$ Tris-HCl, $\mathrm{pH} \mathrm{8,} 50 \mathrm{mg} \mathrm{L}^{-1}$ ARNase, $0.3 \mathrm{M}$ sucrose). After incubation during $2 \mathrm{~h}$ at $37{ }^{\circ} \mathrm{C}$ to improve cell lysis, $250 \mu \mathrm{L}$ sodium dodecyl sulfate (SDS) $2 \%(\mathrm{w} / \mathrm{v})$ were added, the solution was vortexed for 1 min, and then $2 \mu \mathrm{L} \beta$-mercaptoethanol added and incubated $30 \mathrm{~min}$ at $60{ }^{\circ} \mathrm{C}$. To purify DNA, 1 volume of chloroform:isoamyl alcohol (24:1) was added. The solution was mixed and centrifuged (12000 rpm, $15 \mathrm{~min}$ ). After separation of the aqueous phase, 1 volume of 2-propanol was added and the solution incubated at $-20{ }^{\circ} \mathrm{C}$ during $1 \mathrm{~h}$ to facilitate DNA precipitation. The precipitated DNA was washed with 1 volume of $70 \%$ (v/v) ethanol and dried. Finally, the DNA was re-suspended in $50 \mu \mathrm{L}$ sterile distilled water. Purity of extracted DNA was assessed by measuring the 260/280 and 260/230 ratios using a spectrophotometer. DNA concentration was measured using Quanti-iT dsDNA Assay kit (Invitrogen, Paisley, UK). for up to $1.5 \mathrm{~h}$. The aliquot of each digestion reactions was analyzed on $2 \%(\mathrm{w} / \mathrm{v})$ agarose gel and completed if the majority of DNA fragments had a size range of 2001000 base pairs (bp). This resulted in the production of fragments 200 to 1000 bases in 
171 length. The resulted DNA was precipitated with isopropanol, suspended in $45 \mu \mathrm{L}$ of 172 MilliQ water and used for labelling. We labelled total DNA by direct incorporation of 173 Cy5-conjugated dUTP (GE Healthcare) using terminal deoxynucleotidyl transferase 174 (Thermo Scientific, Paisley, UK). Following a $4 \mathrm{~h}$ incubation at $37{ }^{\circ} \mathrm{C}$, the reaction 175 terminated by addition of $0.5 \mathrm{M}$ EDTA, $\mathrm{pH}$ 8.0. The labelled target was purified from 176 unincorporated dye molecules by adding $200 \mu \mathrm{L}$ of TE buffer and spinning through a 177 Microcone filter (Millipore, Hertfordshire, UK) for 15 minutes at $11000 \mathrm{rpm}$. The purified, labelled target was precipitated with isopropanol, and resuspended to a final volume of $20 \mu \mathrm{L}$ with MilliQ water. The dye incorporation was measured with a NanoDrop spectrophotometer. Labelled DNA samples were vacuum-dried and stored at $-20^{\circ} \mathrm{C}$ until hybridization.

We used a chip previously designed and calibrated by Vilchez-Vargas et al. (2013). For microarray hybridization, probes were printed on CodeLink Activated slides 184 (SurModics, Eden Prairie, USA) using MicroGrid TAS II spotter (BioRobotics, Germany) at the University of Frankfurt (Frankfurt, Germany). Coupling of DNA probes was performed by overnight incubation of slides in saturated $\mathrm{NaCl}$ chamber. Post-coupling processing included the blocking of residual reactive groups and was done as follows: slides were washed with 4x SSC (190 mM sodium chloride plus 20 $\mathrm{mM}$ tri-sodium citrate equivalent to sodium concentration of $250 \mathrm{mM}), 0.1 \%(\mathrm{w} / \mathrm{v})$ SDS, for $30 \mathrm{~min}$, then rinsed briefly with deionized water and dried by centrifugation for $3 \mathrm{~min}$ at low-speed centrifuge. Prior to hybridization, labelled DNA was incubated with herring sperm DNA (Invitrogen, Paisley, UK) for 5 min at $95^{\circ} \mathrm{C}$ and then $80 \mu \mathrm{L}$ of hybridization buffer was added. For hybridization, slides were inserted into hybridization chamber and after that were covered by coverslips. The solution of Cy5 - 
dUTP labelled DNA in hybridization buffer (100 $\mu \mathrm{L}$ total volume) was carefully infused through narrow gaps between slides and covers.

The hybridization was performed at $55{ }^{\circ} \mathrm{C}$ for $18 \mathrm{~h}$ using hybridization buffer consisting of $15 \%(\mathrm{v} / \mathrm{v})$ dimethylsulfoxide, $25 \%(\mathrm{v} / \mathrm{v})$ formamide, $1.25 \times \mathrm{SSC}, 0.15 \%$ (w/v) SDS, $0.15 \%(w / v)$ Tween 20, $880 \mathrm{mM}$ betaine, $5 x$ TE buffer (50 mM Tris-HCl, 5 $\mathrm{mM}$ EDTA) and $0.1 \mathrm{mg} \mathrm{\textrm {L } ^ { - 1 }}$ bovine serum albumin (BSA) in aqueous solution. Following hybridization, slides were washed $5 \mathrm{~min}$ at $42^{\circ} \mathrm{C}$ in $1 \mathrm{x}$ SSC containing $0.3 \%$ (w/v) SDS, twice in $1 x \operatorname{SSC}\left(1 \mathrm{~min}, 42^{\circ} \mathrm{C}\right)$, in $0.5 \mathrm{x} \mathrm{SSC}\left(1 \mathrm{~min}, 20{ }^{\circ} \mathrm{C}\right)$, in $0.1 \mathrm{x} \mathrm{SSC}$ containing $0.3 \%(\mathrm{w} / \mathrm{v}) \operatorname{SDS}\left(1 \mathrm{~min}, 42^{\circ} \mathrm{C}\right)$ and finally twice in $0.1 \mathrm{x} \operatorname{SSC}\left(1 \mathrm{~min}, 20^{\circ} \mathrm{C}\right)$.

Slides were dried at low speed in centrifuge for 30 seconds. Slides were scanned in a analyzed by using the software of image analysis GenePixRPro 6.0 from Axon Instruments / Molecular Devices Corp (Molecular Devices, Berkshire, UK). in Supplementary Table S1) for which a positive signal was obtained in the microarray was submitted to web-based AromaDeg resource (Duarte et al. 2014). Each sequence was then associated with a catabolic enzyme performing an aromatic compound degradation reaction.

Quantification of the biodegradation of hydrocarbons by cultivation and liquid chromatography-mass spectrometry

215 Activation of the DSM 45259 strain was firstly done by transfers in minimal-mineral medium with a low concentration of hydrocarbon $\left(20 \mathrm{mg} \mathrm{L}^{-1}\right)$ for the adaptation of the

217 microorganism. The medium consisted of $2.6 \mathrm{~g} \mathrm{Na}_{2} \mathrm{HPO}_{4}, 1.33 \mathrm{~g} \mathrm{KH}_{2} \mathrm{PO}_{4}, 1 \mathrm{~g}$ 218 $\left(\mathrm{NH}_{4}\right)_{2} \mathrm{SO}_{4}$ and $0.20 \mathrm{~g} \mathrm{MgSO}_{4} \cdot 7 \mathrm{H}_{2} \mathrm{O}$ dissolved in $1000 \mathrm{~mL}$ of demineralized water. The 
medium was adjusted to $\mathrm{pH} 7.2 \pm 0.3$. After sterilization, $5 \mathrm{~mL}$ of trace element solution and $1 \mathrm{~mL}$ of vitamin solution were added. Both solutions were prepared as described in DSMZ methanogenium medium 141 and autoclaved or sterile filtered separately ([DSMZ 2012]). Substrates were sterilized separately and added aseptically at an amount of $20 \mathrm{mg} \mathrm{L}^{-1}$ each. Cultivation was done at $30{ }^{\circ} \mathrm{C}$ with a $180 \mathrm{rpm}$ constant agitation during $72 \mathrm{~h}$. The cell biomass was washed twice with $20 \mathrm{mM}$ sodium phosphate buffer $\mathrm{pH} 7.0$ and used to produce cultures. Briefly, cell pellets were grown in $30 \mathrm{~mL}$ of the same medium $\left(0.4 \mathrm{~g}\right.$ wet cell pellet $\left.\mathrm{L}^{-1}\right)$ with various aliphatic and aromatic hydrocarbons such as $n$-decane, $n$-tetradecane, phenol, benzoate and phthalate to serve as the sole source of carbon and energy. Substrates were sterilized separately and added aseptically at an amount of $500 \mathrm{mg} \mathrm{L}^{-1}$ each. Cultivation was done at $30{ }^{\circ} \mathrm{C}$ with a $180 \mathrm{rpm}$ constant agitation during $72 \mathrm{~h}$. Two controls were done: a control test without the addition of the cells (abiotic test) and a control test without the addition of the hydrocarbon (biotic test).

The extraction of the hydrocarbons and their degradation intermediates was performed by adding 1 volume of acetone to the cultures. After homogenization, flasks were stand for $30 \mathrm{~min}$, and then centrifuged at $13000 \mathrm{rpm}$ during $10 \mathrm{~min}$. The supernatants were analyzed by target analysis by Liquid Chromatography (LC)-Mass Spectrometry (MS) to confirm the degradation of the initial substrates as well as the existence of degradation intermediates in test and control cultures. For that, the following reagents and standards have been used: acetonitrile (LC-MS grade, SigmaAldrich, Steinheim, Germany), formic acid (FA) (MS grade, Sigma-Aldrich, Steinheim,

241 Germany) and MilliQ ${ }^{\circledR}$ water (Millipore, Billerica, MA, USA). For reference masses 242 purine, hexakis $(1 \mathrm{H}, 1 \mathrm{H}, 3 \mathrm{H}$-tetrafluoropropoxy)phosphazine $(\mathrm{HP})$ and ammonium trifluoroacetate $\left(\mathrm{TFA}\left(\mathrm{NH}_{4}\right)\right.$ ) from Agilent (API-TOF reference mass solution kit) were 
used. The metabolic profile was achieved using a liquid chromatography system consisting of a degasser, a binary pump, and an auto-sampler (1290 infinity II, Agilent). Samples $(0.5 \mu \mathrm{L})$ were applied to a reversed-phase column (Zorbax Extend C18 $50 \mathrm{x}$ $2.1 \mathrm{~mm}, 1.8 \mu \mathrm{m}$; Agilent), which was maintained at $60{ }^{\circ} \mathrm{C}$ during the analysis. The system was operated at a flow rate of $0.6 \mathrm{~mL} \mathrm{~min}^{-1}$ with solvent A (water containing $0.1 \%$ formic acid) and solvent $\mathrm{B}$ (acetonitrile containing $0.1 \%$ formic acid). The gradient was $5 \% \mathrm{~B}(0-1 \mathrm{~min}), 5$ to $80 \% \mathrm{~B}(1-7 \mathrm{~min}), 80$ to $100 \% \mathrm{~B}(7-11.5 \mathrm{~min})$, and 100 to $5 \% \mathrm{~B}(11.5-12 \mathrm{~min})$. The system was finally held at $5 \% \mathrm{~B}$ for $3 \mathrm{~min}$ to reequilibrate the system (15 min of total analysis time). Data were collected in positive and negative ESI modes in separate runs using QTOF (Agilent 6550 iFunnel). The analyses were performed in both positive and negative ion modes in full-scan from $\mathrm{m} / \mathrm{z}$ 50 to 1000 . The capillary voltage was $3000 \mathrm{~V}$ and the nozzle voltage was $1000 \mathrm{~V}$ with a scan rate of 1.0 spectrum per second. The gas temperature was $250{ }^{\circ} \mathrm{C}$, the drying gas flow was $12 \mathrm{~L} \mathrm{~min}^{-1}$, the nebulizer was $52 \mathrm{psi}$, the sheath gas temperature $370{ }^{\circ} \mathrm{C}$ and the sheath gas flow $11 \mathrm{~L} \mathrm{~min}^{-1}$. For positive mode, the MS-TOF parameters were as follows: fragmentor $175 \mathrm{~V}$ and octopole radio frequency voltage $750 \mathrm{~V}$. For negative mode, the MS-TOF parameters included the following: fragmentor $250 \mathrm{~V}$ and octopole radio frequency voltage $750 \mathrm{~V}$. During the analyses, two reference masses were used: 121.0509 (purine, detected $\mathrm{m} / z,\left[\mathrm{C}_{5} \mathrm{H}_{4} \mathrm{~N}_{4}+\mathrm{H}\right]^{+}$) and 922.0098 (HP, detected $\mathrm{m} / \mathrm{z}$ $\left.\left[\mathrm{C}_{18} \mathrm{H}_{18} \mathrm{O}_{6} \mathrm{~N}_{3} \mathrm{P}_{3} \mathrm{~F}_{24}+\mathrm{H}\right]^{+}\right)$in positive mode and $112.9856\left(\mathrm{TFA}\left(\mathrm{NH}_{4}\right)\right.$, detected $\mathrm{m} / \mathrm{z}$ $\left.\left[\mathrm{C}_{2} \mathrm{O}_{2} \mathrm{~F}_{3}\left(\mathrm{NH}_{4}\right)-\mathrm{H}\right]^{-}\right)$and $966.0007\left(\mathrm{HP}+\mathrm{FA}\right.$, detected $\left.\mathrm{m} / z,\left[\mathrm{C}_{18} \mathrm{H}_{18} \mathrm{O}_{6} \mathrm{~N}_{3} \mathrm{P}_{3} \mathrm{~F}_{24}+\mathrm{FA}-\mathrm{H}\right]^{-}\right)$in negative mode. The references were continuously infused into the system, enabling constant mass correction. Samples were analyzed in randomized runs, during which 
were set up starting with the analysis of ten equilibrium injections followed by the samples. A single injection per sample was done.

Based on a list of candidates, their accurate monoisotopic masses were searched for in the MS chromatograms ( $\pm 10 \mathrm{ppm})$ using MassHunter Quantitative Analysis (B.06.00, Agilent) and their identification confirmed by the analysis of the commercial standards. Then, the corresponding peak areas were integrated using the same software.

\section{Determination of catechol dioxygenase activity}

To investigate the catechol 2,3-dioxygenase activity, a spectrophotometric method was used, in which the formation of oxidation products is followed. Briefly, the strain was pre-cultivated in minimal-mineral medium as described before at $30{ }^{\circ} \mathrm{C}$ until exponential phase using benzoate and phenol as sole carbon sources $\left(20 \mathrm{mg} \mathrm{L}^{-1}\right)$. This culture was used to inoculate $30 \mathrm{~mL}$ of minimal-mineral medium containing $500 \mathrm{mg} \mathrm{L}^{-1}$ of benzoate and phenol, respectively (for details see above). Control cultures without the addition of hydrocarbons were done. Cultures were incubated at $30{ }^{\circ} \mathrm{C}$ at $180 \mathrm{rpm}$ during $72 \mathrm{~h}$, after which cells were separated by centrifugation $(8000 \mathrm{rpm}$; $10 \mathrm{~min}$; 4 ${ }^{\circ} \mathrm{C}$ ). The pellet was washed twice with $50 \mathrm{mM} \mathrm{K} / \mathrm{Na}$-phosphate (pH 7.5) buffer, and then re-suspended in $5 \mathrm{~mL}$ of this buffer. For the preparation of protein cell extracts, the cells were broken by three passages in a French Press ${ }^{\circledR}$ at 20000 psi, after which the sample was centrifuged $\left(10000 \mathrm{rpm} ; 10 \mathrm{~min} ; 4^{\circ} \mathrm{C}\right)$ to eliminate cell debris. Supernatant was carefully aspirated and immediately used for activity assay. The assay was performed in 96-well plates and $200 \mu \mathrm{L}$ of total volume, as described elsewhere (Alcaide et al. 2013). Briefly, the catechol 2,3-dioxygenase activity was measured (in triplicates) in a microplate reader (Synergy HT Multi-Mode Microplate Reader BioTek) by evaluating the increase of absorbance at $388 \mathrm{~nm}$ due to the formation of the 
reaction product 2-hydroxy-6-oxohepta-2,4-dienoate (HOHD), in a reaction mixture that contains $10 \mu \mathrm{L}$ of protein extract containing catechol 2,3-dioxygenase to a substrate in

294 the presence of the following solution: $87 \mu \mathrm{L}$ of K/Na-phosphate (pH 7.5) and $3 \mu \mathrm{L}$ of catechol solution in $\mathrm{H}_{2} \mathrm{O}(10 \mathrm{mM})$ to achieve a final substrate concentration of 0.15 $\mathrm{mM}$. Reactions were followed at $30{ }^{\circ} \mathrm{C}$ for $20 \mathrm{~min}\left(\varepsilon_{\mathrm{HOHD}}\right.$ at $\left.388 \mathrm{~nm}=13,800 \mathrm{M}^{-1} \mathrm{~cm}^{-1}\right)$. One unit (U) of enzyme activity was defined as the amount of enzyme required to transform $1 \mu \mathrm{mol}$ of substrate in 1 min under the assay conditions.

\section{Results}

\section{Degradation capacities of DSM45259 guided by microarray data}

Catabolome microarray data from A. tucumanensis DSM 45259, grown in napthalene and glucose as co-substrate constituted the input information in our study. The complete information about the microarray tests is described in the Materials and Methods section. Following the restrictive criterion of fold-change above 6-fold higher than background signal in the internally calibrated microarray system, we detect a total of 5 out of 3605 genes encoding proteins with proved catabolic functions (Table 1). As mentioned, to detect signals with a high precision, only signals $>6$ normalized intensity (NI) were considered, as the use of internal positive controls for setting the correct threshold according to the desired precision of the experiment revealed that, under conditions described in Materials and Methods, any signal $>6-8 \mathrm{NI}$ is highly unlikely to be false positive (Vilchez-Vargas et al. 2013). Raw fluorescence signals for probes targeting the 3605 genes are detailed in Supplementary Table 1. Within the 11 catabolic genes families targeted by the microarray (Vilchez-Vargas et al. 2013), we detected the presence of 4 covered by the 5 positive probes, which are summarized below. 
Genes implicated in alkane degradation were found. Particularly, the probes targeting alkB genes AJ833983 and AJ833926 for AlkB alkane hydroxylases (the so-

317 called ALKB catabolic gene family by Vilchez-Vargas et al. 2013) were strongly detected (Table 1). AlkB participates in the initial attack of n-alkenes in the $n$-alkane oxidation pathway (Fig. 1). Within ring hydroxylating dioxygenases (RHDO catabolic gene family) we found AAD17377 by a high intensity of hybridization, followed by

AAD03558 (Table 1). According to AromaDeg (Duarte et al. 2014), AAD17377 gene encodes a benzoate 1,2-dioxygenase (Bzt) that convert benzoate into cis-1,6-dihydroxy2,4-cyclohexadiene-1-carboxylic acid within the benzoate to catechol degradation pathway, and AAD03558 a phthalate 4,5- dioxygenase (Pht) that converts phthalate into protocatechuate. Finally, within ring hydroxylating monooxygenases (RHMO catabolic gene family) we found Z36909, which was the probe with the highest level of hybridization intensity (Table 1), and that encodes a phenol hydroxylase, an enzyme that catalyzes the first step in the degradation of phenol into catechol.

Taken together, the microarray data support the ability of the DSM 45259 strain to utilize single alkanes and aromatics such as benzoate and phenol (through conversion to catechol) and phthalate (through conversion to protocatechuate) as carbon sources (Fig. 1). Interestingly alkB gene in the strain DSM 45259 matches with two probes (AJ833983 and AJ833926) encoding the same protein, namely, an alkane hydroxylase (AlkB) from actinomycete Rhodococcus species; this matches with the taxonomy of strain DSM 45259. Indeed, several actinomycetes able to degrade $\mathrm{C}_{5}-\mathrm{C}_{10}$ alkanes contain alkane hydroxylases as, for example, representatives from mycobacteria and rhodococci (van Beilen et al. 2005; Sekine et al. 2006; Lincoln et al. 2015). By contrast, genes encoding Bzt (AAD17377) and Pht (AAD03558) match with probes from Proteobacteria (Sphingobium and Burkholderia spp.), and that of the phenol 
hydroxylase (Z36909) to a probe from Acinetobacter sp. This suggests that alkB gene in DSM 45259 strain is highly similar to that found in other actinomycetes, while the other 3 genes are quite divergent to those from actinomycetes.

Note that no any other gene implicated in the later stages of the degradation of alkanes, apart from alkB, was detected in the microarray because it does not contains such genes (Vilchez-Vargas et al. 2013). In the case of genes implicated in the later stages of the degradation of protocatechuate, phenol and catechol, the microarray contains probes encoding catechol-2,3-dioxygenases (Cat) within the so-called extradiol dioxygenases (EXDO) catabolic gene family, and catechol 1,2-dioxygenases and protocatechuate 3,4-dioxygenases $(3,4-\mathrm{PCD})$ within the so-called intradiol dioxygenase (INDO) catabolic gene family. None of those genes were detected in the microarray according to 6 fold-change criterion, suggesting the absence or low expression level of those genes in strain DSM 45259 under our assay conditions. Indeed, the DNA material used for microarray hybridization was obtained from cells harvested during late exponential growth phase in cultures containing glucose and naphtalene as carbon sources, where those genes may be expressed at low level. This is in agreement with cultivation, activity tests and mass spectrometry experiments (see below) that confirmed that strain DSM 45259 contains 3,4-PCD and Cat activities when grown on phthalate and benzoate (see below), and that in the absence of these substrates expression level of those genes may be most likely low. This is not the case of the genes encoding catechol 1,2-dioxygenase whose presence in the genome of strain DSM 45259 could not be confirmed both by array and cultivation tests (see below).

\section{Experimental validation by cultivation and mass spectrometry}


To prove the correctness of the predictions and to discard that the predictions are an artifact derived from an inaccurate hybridization, experimental validation assays were conducted. For that, cultures were set up with $\mathrm{C}_{10}$ and $\mathrm{C}_{14}$ alkanes (n-decane and $n$ tetradecane), and the aromatics phthalate, phenol and benzoate as the only carbon source, and after $0,24,48$ and $72 \mathrm{~h}$ cultivation we examined the efficiency of strain DSM 45259 to degrade them. A concentration of $500 \mathrm{mg} \mathrm{L}^{-1}$ of each compound was used. Target analysis by Liquid Chromatography-Mass Spectrometry (LC-MS) was further used to confirm the consumption of the initial substrates and the formation of key degradation intermediates in test cultures as compared to the abiotic (culture media containing aromatics but no cells) and biotic (culture without the aromatics) control cultures. both chemicals could not be detected under our analytical platform. However, $n$ decanoic (in $n$-decane microcosm) and $n$-tetradecanoic acid (in the $n$-tetradecane microcosm) were detected at high level (Table 2), demonstrating that the degradation of both alkanes by strain DSM 45259 occurred. Degradation of phthalate, phenol and benzoate was achieved at 49.7, 89.1 and 57.6\%, respectively, at the end of the $72 \mathrm{~h}$ assay. This was shown by measuring the remaining amount of these 3 compounds (Table 2). Degradation was further demonstrated by identifying the increasing abundance level of the phthalic-degradation products protocatechuic acid and 3oxoadipic acid (in phthalate microcosm) and the phenol- and benzoate-degradation product catechol (in phenol and benzoate microcosms) during the follow-up assay (Table 2). The identification of 3-oxoadipic acid in the cultures grown with phthalate in combination to the identification of a gene encoding a phthalate 4,5-dioxygenase in the microarray demonstrate that catabolism of phthalate proceeds via the proto-catechuic 
ortho cleavage pathway in which a protocatechuate 3,4-dioxygenase may be implicated (Fig. 1). In case of catechol degradation, no intermediates were detected above the detection limit by LC-MS, possibly because they are rapidly converted and thus accumulated at low level under cultivation conditions. However, the demonstration of catechol 2,3-dioxygenase activity in protein extracts from cells obtained in cultures grown on benzoate and phenol in MM broth (see Materials and Methods section) revealed that the catechol meta-ring cleavage branch is fully operative in DSM 45259

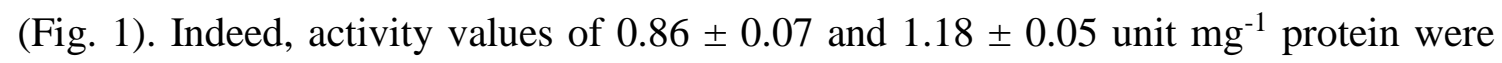
obtained under our experimental assay conditions.

Taken together, as shown in Table 2, signatures for the degradation of the 5 chemicals predicted as being used as carbon sources (Fig. 1) were experimentally found (Table 2), thus confirming a total agreement with our predictions.

\section{Discussion}

In this report, we described new insights into the degradation capacities of the copperresistant actinomycete A. tucumanensis DSM 45259 using microarray data. Our approach was based on the utilization of the catabolome microarray presented by Vilchez-Vargas et al. (2013). However, we adapt the output of the microarray data to incorporate a prediction tool based on the utilization of the web-based AromaDeg resource (Duarte et al. 2014), and identify unambiguously genes encoding catabolic proteins of this microorganism. Further, with cultivation and metabolomics approaches being developed, we provided experimental validation. Based on the microarray and experimental data presented we unambiguously identified that A. tucumanensis DSM 45259 has the ability to use alkanes (i.e., $n$-decane and $n$-tetradecane), phthalate, phenol and benzoate as sole carbon sources. Degradation occurred in the absence of glucose as 
co-substrate that was previously reported to be required for the degradation of naphthalene and phenanthrene (Bourguignon et al. 2014).

Actinomycetes possess potent capacities to metabolize aliphatic and aromatic toxic hydrocarbons. Species of the genera Mycobacterium, Streptomyces and Nocardia (that contain genera such as Gordonia and Rhodococcus), commonly found in contaminated soils, are the best characterized members. Thus, by using cultivation, phylogenetic, phenotypic, and/or genomic information approaches, members of these genera have been shown to use as sole carbon and energy sources, to different extend, a wide range of compounds. They include, crude oil, diesel oil, rapeseed oil, linear and branched medium-to-long chain alkanes (up to $\mathrm{C}_{36}$ ), alkenes, haloalkanes, monocyclic aromatic compounds (benzoate, catechol, gentisate, salicylate, phenol, phenylethanol, thymol, alkylbenzenes, xylene, toluene, phthalate) and poly-aromatic compounds (biphenyl, naphthalene, anthracene, fluoranthrene, phenanthrene, coronene, pyrene, chrysene, naphthacene, acenapthene, benzo[a]pyrene, 7,12-dimethylbenz[a]anthracene), as well as organic sulfur compounds (i.e. benzothiophene and dibenzothiophene) and nitroaromatics (Kelley and Cernigilia, 1995; Lloyd-Jones and Hunter, 1997; Bastiaens et al. 2000; Monticello, 2000; Stingley et al. 2004; Kumar et al. 2006; Larkin et al. 2006; Zeinali et al. 2007; Yang et al. 2011; Balachandran et al. 2012; Fathepure, 2014; Luo et al. 2014; Sudhir et al. 2014). In some case biodegradation was only observed when growing on glucose as co-substrate (Pizzul et al. 2006). Members of the genus Arthrobacter and Streptomyces can also degrade halogenated pesticides (Bourguignon et al. 2014). Terrabacter isolates have been also shown to degrade dibenzofuran and the heterocyclic nitrogen compound carbazole (Iida et al. 2002). Therefore, we can conclude that the degrading capacities herein reported for A. tucumanensis DSM 45259 are within common abilities for other actinomycetes. 
A solid basis of genomic understanding on degradation capacities of actinomycetes has been mainly established, particularly for Mycobacterium and Nocardia isolates. Thus, genome analysis of Mycobacteria isolates has contributed to the characterization of key enzymes such as the initial ring-hydroxylating dioxygenases participating in the degradation of substrates such as biphenyl, naphthalene, anthracene, fluoranthene, pyrene, phenanthrene, phthalate and benzoate (Brezna et al. 2003; Stingley et al. 2004; Kim et al. 2006; Kim et al. 2007; Kim et al. 2008; Kallimanis et al. 2011; Zhang et al. 2012; Kwak et al. 2014). Genome sequence of Rhodococcus strains revealed they contain not only multiple alkane hydroxylase genes (alkB) and from 27 to 73 cytochrome P450 monooxygenases and other catabolic genes predicted to be involved in the metabolism of alkanes and nitroalkanes, as well as an array of cyclic ketones, halogenated aromatics and aromatic hydrocarbons (e.g., benzoate, catechol, gentisate, salicylate, homogentisate, naphthalene, phenanthrene, anthracene, and benzo[a]pyrene) (McLeod et al. 2006; Chen et al. 2013; Pathak et al. 2013; Zhang et al. 2014; Lincoln et al. 2015; Qu et al. 2015). In addition to that, phylogenetic, phenotypic, and genomic information for 27 completely genome-sequenced mycobacteria revealed a total of 9532 genes conforming the so-called "PAH-degrading" node, of which 3533 genes belong to the core-genome that is present in each strain and 5999 genes belong to the dispensable genome that is absent in one or more strains (Kweon et al., 2015). Among the 3533 core genes, only 136 common genes were tentatively identified to be involved in the degradation of aromatic hydrocarbons, which indicate the high variability of gene sequences and degradation abilities within isolates. Some of these common genes, such as the ones needed for pyrene degradation, have been demonstrated to be acquired by horizontal transfer (DeBruyn et al. 2012). This high genomic variability was also 
45259 (those encoding Bzt, Pht and phenol hydroxylase) are quite divergent $(<80 \%$ sequence identity) to those of other actinomycetes. This was suggested as no hybridization signals of such genes were found with any actinomycete-probes of the same subfamily present in the microarray, while hybridizing with those from Proteobacteria.

In conclusion, we report here new insights into the catabolic abilities of the first member of the Amycolatopsis genus and identify a variety of genomic signatures which seems to be uncommon within actinomycetes. This work also contributed to deepening into the degradation capacities of actinomycetes, whose knowledge is mostly limited for Mycobacterium and Nocardia isolates. Note that the genus Amycolatopsis has been classified in the family Pseudonocardiaceae and it currently contains 39 species with validly published names (http://www.bacterio.cict.fr/a/amycolatopsis.html). Recent studies indicate that the chemotaxonomic characteristics of this genus, which relate to, but differentiate from Streptomyces and Nocardia, are intrinsically determined by the molecular phylogeny of their encoding genes (Xu et al. 2014). Its closest relatives are Amycolatopsis sp. ATCC 39116, A. methanolica 239 and A. thermoflava N1165. Amycolatopsis sp. ATCC 39116 (previously known as S. setonii) harbors genes encoding canonical pathways for catabolism of catechol, benzoate, protocatechuate, phenylacetate, and methylated aromatic compound (Davis et al. 2012). A. methanolica 239 (previously known as Streptomyces sp. strain 239 or as Nocardia sp. strain 239) can grow in mineral medium broth containing methanol, ethanol, 1-propanol, 1-butanol, 2,3-butanediol, acetone, benzoic acid methylester, benzylamine, 3- and 4hydroxybenzoates, 3,4-dihydroxybenzoate, phenylacetate, phenylacetaldehyde, phenyllactate, phenylpyruvate, 4-hydroxyphenylacetate, 4-hydroxyphenylpyruvate, Dphenylalanine, gentisate, and homogentisate as sole sources of carbon. Also, it contains 
487 degradation pathways for benzoate, fluorobenzoate, toluene, xylene, styrene, naphthalene and other related polycyclic aromatic hydrocarbons (Wattam et al. 2014). A. thermoflava N1165 has been shown to degrade atrazine, naphthalene, anthracene, tetrachloroethene, 1- and 2-methylnaphthalene, 2,4-dichlorobenzoate, toluene, xylene, biphenyl, hexachlorocyclohexane, trinitrotoluene, ethylbenzene, and styrene (Chun et al. 1999).

Finally, cultivation and mass spectrometry evidences are provided that demonstrated that the catabolome array can aid in the understanding of degrading capacities without previous genome, and possibly metagenome, sequence knowledge.

Acknowledgement This work was supported by the CSIC (Programa CSIC de Cooperación 497 Científica para el Desarrollo i-COOP; ref. COOPB20077), the European Community project KILLSPILL (FP7-KBBE-2012-312139), and the Spanish Ministry of Economy and Competitiveness (CTQ2014-55279-R). N.B. is a recipient of a fellowship from the Consejo Nacional de Investigaciones Científicas y Técnicas (CONICET), Argentina. We thank Drs. Dietmar H. Pieper and Ramiro Vilchez-Vargas for their support in providing resources for this study.

\section{Compliance with ethical standards}

504 Conflict of interest All authors declare that they have no conflict of interest.

505 Human and animal rights This article does not contain any studies with human participants or animals performed by any of the authors.

\section{References}


511 Albarracín VH, Amoroso MJ, Abate CM (2010b) Bioaugmentation of copper polluted soil microcosms with Amycolatopsis tucumanensis to a copper for Zea mays plants. Chemosphere 79(2):131-137.

Alcaide M, Tornés J, Stogios PJ, Xu X, Gertler C, Di Leo R, Bargiela R, Lafraya A, Guazzaroni ME, López-Cortés N, Chernikova TN, Golyshina OV, Nechitaylo TY, Plumeier I, Pieper DH, Yakimov MM, Savchenko A, Golyshin PN, Ferrer M (2013) Single residues dictate the co-evolution of dual esterases: MCP hydrolases from the $\alpha / \beta$ hydrolase family. Biochem J 454(1):157-166.

Bailey MJ, Lilley AK, Thompson IP, Rainey PB, Ellis RJ (1995) Site directed chromosomal marking of a fluorescent pseudomonad isolated from the phytosphere of sugar beet; stability and potential for marker gene transfer. Mol Ecol 4(6):755-763.

Balachandran C, Duraipandiyan V, Balakrishna K, Ignacimuthu S (2012) Petroleum and polycyclic aromatic hydrocarbons (PAHs) degradation and naphthalene metabolism in Streptomyces sp. (ERI-CPDA-1) isolated from oil contaminated soil. Bioresour Technol 112:83-90.

Bargiela R, Gertler C, Magagnini M, Mapelli F, Chen J, Daffonchio D, Golyshin PN, Ferrer M (2015) Degradation network reconstruction in uric acid and ammonium amendments in oildegrading marine microcosms guided by metagenomic data. Front Microbiol 6:1270.

Bargiela R, Mapelli F, Rojo D, Chouaia B, Tornés J, Borin S, Richter M, Del Pozo MV, Cappello S, Gertler C, Genovese M, Denaro R, Martínez-Martínez M, Fodelianakis S, Amer RA, Bigazzi D, Han X, Chen J, Chernikova TN, Golyshina OV, Mahjoubi M, Jaouanil A, Benzha F, Magagnini M, Hussein E, Al-Horani F, Cherif A, Blaghen M, Abdel-Fattah YR, Kalogerakis N, Barbas C, Malkawi HI, Golyshin PN, Yakimov MM, Daffonchio D, Ferrer M (2015) Bacterial population and biodegradation potential in chronically crude oil-contaminated marine sediments are strongly linked to temperature. Sci Rep 5:11651. 
Bastiaens L, Springael D, Wattiau P, Harms H, deWachter R, Verachtert H, Diels L (2000) Isolation of adherent polycyclic aromatic hydrocarbon (PAH)-degrading bacteria using PAH-sorbing carriers. Appl Environ Microbiol 66(5):1834-1843.

Beazley MJ, Martinez RJ, Rajan S, Powell J, Piceno YM, Tom LM, Andersen GL, Hazen TC, Van Nostrand JD, Zhou J, Mortazavi B, Sobecky PA (2012) Microbial community analysis of a coastal salt marsh affected by the Deepwater Horizon oil spill. PLoS One 7:e41305.

Bourguignon N, Fuentes MS, Benimeli CS, Cuozzo SA, Amoroso MJ (2014) Aerobic removal of methoxychlor by a native Streptomyces strain: Identification of intermediate metabolites. Int Biodeter Biodegr 96:80-86.

Bourguignon N, Isaac P, Alvarez H, Amoroso MJ, Ferrero MA (2014) Enhanced polyaromatic hydrocarbon degradation by adapted cultures of actinomycete strains. J Basic Microbiol 54(12):1288-1294.

Brezna B, Khan AA, Cerniglia CE (2003) Molecular characterization of dioxygenases from polycyclic aromatic hydrocarbon-degrading Mycobacterium spp. FEMS Microbiol Lett 223(2):177-183.

Chen BS, Otten LG1, Resch V1, Muyzer G2, Hanefeld U1 (2013) Draft genome sequence of Rhodococcus rhodochrous strain ATCC 17895. Stand Genomic Sci 9(1):175-184.

Chun J, Kim SB, Oh YK, Seong CN,Lee DH, Bae KS, Lee KJ,Kang SO, Hah YC, Goodfellow M (1999) Amycolatopsis thermoflava sp. nov., a novel soil actinomycete from Hainan Island, China. Int J Syst Bacteriol 49:1369-1373.

Colin VL, Castro MF, Amoroso MJ, Villegas LB (2013) Production of bioemulsifiers by Amycolatopsis tucumanensis DSM 45259 and their potential application in remediation technologies for soils contaminated with hexavalent chromium. J Hazard Mater 261:577583. 
Dávila Costa JS, Albarracín VH, Abate CM (2011a) Cupric reductase activity in copperresistant Amycolatopsis tucumanensis. Water Air Soil Pollut 216:527-535.

Dávila Costa JS, Albarracín VH, Abate CM (2011b) Responses of environmental Amycolatopsis strains to copper stress. Ecotoxicol Environ Saf 74(7):2020-2028.

Dávila Costa JS, Kothe E, Abate CM, Amoroso MJ (2012) Unraveling the Amycolatopsis tucumanensis copper-resistome. Biometals 25(5):905-917.

Davis JR, Goodwin LA, Woyke T, Teshima H, Bruce D, Detter C, Tapia R, Han S, Han J, Pitluck S, Nolan M, Mikhailova N, Land ML, Sello JK (2012) Genome sequence of Amycolatopsis sp. strain ATCC 39116, a plant biomass-degrading actinomycete. J Bacteriol 194(9):2396-2397.

DeBruyn JM, Mead TJ, Sayler GS. Horizontal transfer of PAH catabolism genes in Mycobacterium: evidence from comparative genomics and isolated pyrene-degrading bacteria. Environ Sci Technol 46(1):99-106.

Duarte M, Jauregui R, Vilchez-Vargas R, Junca H, Pieper DH (2014) AromaDeg, a novel database for phylogenomics of aerobic bacterial degradation of aromatics. Database (Oxford) 2014:bau118.

Fathepure BZ (2014) Recent studies in microbial degradation of petroleum hydrocarbons in hypersaline environments. Front Microbiol 5:173.

Guazzaroni M-E, Herbst FA, Lores I, Tamames J, Peláez AI, López-Cortés N, Alcaide M, Del Pozo MV, Vieites JM, von Bergen M, Gallego JL, Bargiela R, López-López A, Pieper DH, Rosselló-Móra R, Sánchez J, Seifert J, Ferrer M (2013) Metaproteogenomic insights beyond bacterial response to naphthalene exposure and bio-stimulation. ISME J 7(1):122136. 
Gutierrez T, Singleton DR, Berry D, Yang T, Aitken MD, Teske A (2013) Hydrocarbondegrading bacteria enriched by the Deepwater Horizon oil spill identified by cultivation and DNA-SIP. ISME J 7(11):2091-2104.

Hamzah RY, Al-Baharna BS (1994) Catechol ring-cleavage in Pseudomonas cepacia: the simultaneous induction of ortho and meta pathways. Appl Microbiol Biotechnol 41(2):250256.

Hazen TC, Dubinsky EA, DeSantis TZ, Andersen GL, Piceno YM, Singh N, Jansson JK, Probst A, Borglin SE, Fortney JL, Stringfellow WT, Bill M, Conrad ME, Tom LM, Chavarria KL, Alusi TR, Lamendella R, Joyner DC, Spier C, Baelum J, Auer M, Zemla ML, Chakraborty R, Sonnenthal EL, D'haeseleer P, Holman HY, Osman S, Lu Z, Van Nostrand JD, Deng Y, Zhou J, Mason OU (2010) Deep-sea oil plume enriches indigenous oil-degrading bacteria. Science 330(6001):204-208.

Iida T, Mukouzaka Y, Nakamura K, Kudo T (2002) Plasmid-borne genes code for an angular dioxygenase involved in dibenzofuran degradation by Terrabacter sp. strain YK3. Appl Environ Microbiol 68(8):3716-3723.

Kallimanis A, Karabika E, Mavromatis K, Lapidus A, Labutti KM, Liolios K, Ivanova N, Goodwin L, Woyke T, Velentzas AD, Perisynakis A, Ouzounis CC, Kyrpides NC, Koukkou AI, Drainas C (2011) Complete genome sequence of Mycobacterium sp. strain (Spyr1) and reclassification to Mycobacterium gilvum Spyr1. Stand Genomic Sci 5(1):144153.

Kelley I, Cernigilia CE (1995) Degradation of a mixture of high-molecular-weight polycyclic aromatic hydrocarbons by a Mycobacterium strain PYR-1. J Soil Contam 4(1):77-91.

Kim SJ, Kweon O, Freeman JP, Jones RC, Adjei MD, Jhoo JW, Edmondson RD, Cerniglia CE (2006) Molecular cloning and expression of genes encoding a novel dioxygenase involved 
Kim SJ, Kweon O, Jones RC, Edmondson RD, Cerniglia CE (2008) Genomic analysis of polycyclic aromatic hydrocarbon degradation in Mycobacterium vanbaalenii PYR-1. Biodegradation 19(6):859-881.

Kim SJ, Kweon O, Jones RC, Freeman JP, Edmondson RD, Cerniglia CE (2007) Complete and integrated pyrene degradation pathway in Mycobacterium vanbaalenii PYR-1 based on systems biology. J Bacteriol 189(2):464-472.

Kimes NE, Callaghan AV, Aktas DF, Smith WL, Sunner J, Golding B, Drozdowska M, Hazen TC, Suflita JM, Morris PJ (2013) Metagenomic analysis and metabolite profiling of deepsea sediments from the Gulf of Mexico following the Deepwater Horizon oil spill. Front Microbiol 4:50.

Kostka JE, Prakash O, Overholt WA, Green SJ, Freyer G, Canion A, Delgardio J, Norton N, Hazen TC, Huettel M (2011) Hydrocarbon-degrading bacteria and the bacterial community response in gulf of Mexico beach sands impacted by the deepwater horizon oil spill. Appl Environ Microbiol 77(22):7962-7974.

Kubota M, Nodate M, Yasumoto-Hirose M, Uchiyama T, Kagami O, Shizuri Y, Misawa N (2005) Isolation and functional analysis of cytochrome P450 CYP153A genes from various environments. Biosci Biotechnol Biochem 69(12):2421-2430.

Kwak Y, Park GS1, Lee SE1, Li QX2, Shin JH3 (2014) Genome sequence of Mycobacterium aromaticivorans JS19b1(T), a novel isolate from Hawaiian soil. J Biotechnol 186:137-138.

Kweon O, Kim SJ, Blom J, Kim SK, Kim BS, Baek DH, Park SI, Sutherland JB, Cerniglia CE (2015) Comparative functional pan-genome analyses to build connections between genomic dynamics and phenotypic evolution in polycyclic aromatic hydrocarbon metabolism in the genus Mycobacterium. BMC Evol Biol 15:21. 
Larkin MJ, Kulakov LA, Allen CC (2006) Biodegradation by members of the genus Rhodococcus: biochemistry, physiology, and genetic adaptation. Adv Appl Microbiol 59:129.

Liang Y, Van Nostrand JD, Deng Y, He Z, Wu L, Zhang X, Li G, Zhou J (2011) Functional gene diversity of soil microbial communities from five oil-contaminated fields in China. ISME J 5(3):403-413.

Lincoln SA, Hamilton TL, Valladares Juárez AG, Schedler M, Macalady JL, Müller R, Freeman KH (2015) Draft genome sequence of the piezotolerant and crude oil-degrading bacterium Rhodococcus qingshengii strain TUHH-12. Genome Announc 3(2) pii: e00268-15.

Lloyd-Jones G, Hunter DW (1997) Characterization of fluoranthene- and pyrene-degrading Mycobacterium-like strains by RAPD and SSU sequencing. FEMS Microbiol Lett 153(1):51-56.

Lu Z, Deng Y, Van Nostrand JD, He Z, Voordeckers J, Zhou A, Lee YJ, Mason OU, Dubinsky EA, Chavarria KL, Tom LM, Fortney JL, Lamendella R, Jansson JK, D'haeseleer P, Hazen TC, Zhou J (2012) Microbial gene functions enriched in the Deepwater Horizon deep-sea oil plume. ISME J 6(2):451-460.

Luo Q, Hiessl S, Steinbüchel A (2014) Functional diversity of Nocardia in metabolism. Environ Microbiol 16(1):29-48.

Mason OU, Hazen TC, Borglin S, Chain PS, Dubinsky EA, Fortney JL, Han J, Holman HY, Hultman J, Lamendella R, Mackelprang R, Malfatti S, Tom LM, Tringe SG, Woyke T, Zhou J, Rubin EM, Jansson JK (2012) Metagenome, metatranscriptome and single-cell sequencing reveal microbial response to Deepwater Horizon oil spill. ISME J 6(9):17151727.

Mason OU, Scott NM, Gonzalez A, Robbins-Pianka A, Bælum J, Kimbrel J, Bouskill NJ, Prestat E, Borglin S, Joyner DC, Fortney JL, Jurelevicius D, Stringfellow WT, Alvarez- 

sediment microbial community response to Deepwater Horizon oil spill. ISME J 8(7):146475.

McLeod MP1, Warren RL, Hsiao WW, Araki N, Myhre M, Fernandes C, Miyazawa D, Wong W, Lillquist AL, Wang D, Dosanjh M, Hara H, Petrescu A, Morin RD, Yang G, Stott JM, Schein JE, Shin H, Smailus D, Siddiqui AS, Marra MA, Jones SJ, Holt R, Brinkman FS, Miyauchi K, Fukuda M, Davies JE, Mohn WW, Eltis LD (2006) The complete genome of Rhodococcus sp. RHA1 provides insights into a catabolic powerhouse. Proc Natl Acad Sci USA 103(42):15582-7.

Monticello DJ (2000) Biodesulfurization and the upgrading of petroleum distillates. Curr Opin Biotechnol 11(6):540-6.

Nozaki M, Kagamiyama H, Hayaishi O (1963) Metapyrocatechase. I. Purification, crystallization and some properties. Biochemische Z 338:582-590.

Pandey J, Chauhan A, Jain RK (2009) Integrative approaches for assessing the ecological sustainability of in situ bioremediation. FEMS Microbiol Rev 33(2):324-375.

Pathak A, Green SJ, Ogram A, Chauhan A (2013) Draft genome sequence of Rhodococcus opacus strain M213 shows a diverse catabolic potential. Genome Announc 1(1) pii: e00144-12.

Pérez-Pantoja D, De la Iglesia R, Pieper DH, González B (2008) Metabolic reconstruction of aromatic compounds degradation from the genome of the amazing pollutant-degrading bacterium Cupriavidus necator JMP134. FEMS Microbiol Rev 32(5):736-794.

Pérez-Pantoja D, Donoso R, Agulló L, Córdova M, Seeger M, Pieper DH, González B (2012) Genomic analysis of the potential for aromatic compounds biodegradation in Burkholderiales. Environ Microbiol 14(5):1091-1117. 
Pizzul L, Castillo MP, Strenström J (2006) Characterization of selected actinomycetes degrading polyaromatics hydrocarbons in liquid culture and spiked soil. World J Microbiol Biotechnol 22(7):745-752.

Qu J, Miao LL, Liu Y, Liu ZP (2015) Complete genome sequence of Rhodococcus sp. Strain IcdP1 shows diverse catabolic potential. Genome Announc 3(4) pii: e00711-15.

Sekine M., S. Tanikawa, S. Omata, M. Saito, T. Fujisawa, N. Tsukatani, T. Tajima, T. Sekigawa, Kosugi H, Matsuo Y, Nishiko R, Imamura K, Ito M, Narita H, Tago S, Fujita N, Harayama S (2006) Sequence analysis of three plasmids harboured in Rhodococcus erythropolis strain PR4. Environ Microbiol 8(2):334-346.

Seo JS, Keum YS, Li QX (2009) Bacterial degradation of aromatic compounds. Int J Environ Res Public Health 6(1):278-309.

Seo JS, Keum YS, Li QX (2012) Mycobacterium aromativorans JS19b1(T) degrades phenanthrene through C-1,2, C-3,4 and C-9,10 dioxygenation pathways. Int Biodeterior Biodegradation 70:96-103.

Shen FT, Lin JL, Huang CC, Ho YN, Arun AB, Young LS, Young CC. Shen FT, Lin JL, Huang CC, Ho YN, Arun AB, Young LS, Young CC (2009) Molecular detection and phylogenetic analysis of the catechol 1,2-dioxygenase gene from Gordonia spp. Syst Appl Microbiol 32(5):291-300.

Stingley RL, Brezna B, Khan AA, Cerniglia CE (2004) Novel organization of genes in a phthalate degradation operon of Mycobacterium vanbaalenii PYR-1. Microbiology 150(11):3749-3761.

Sudhir KS, Hai G, Modi DR, Joyotsana KP (2014) Growth potential assessment of actinomycetes isolated from petroleum contaminated soil. J Bioremed Biodeg 5:7

van Beilen J.B., R. Holtackers, D. Luscher, U. Bauer, B. Witholt, W.A. Duetz (2005) Biocatalytic production of perillyl alcohol from limonene by using a novel Mycobacterium 
van Beilen JB, Funhoff EG, van Loon A, Just A, Kaysser L, Bouza M, Holtackers R, Röthlisberger M, Li Z, Witholt B (2006) Cytochrome P450 alkane hydroxylases of the CYP153 family are common in alkane-degrading eubacteria lacking integral membrane alkane hydroxylases. Appl Environ Microbiol 72(1):59-65.

Vila J, López Z, Sabaté J, Minguillón C, Solanas AM, Grifoll M (2001) Identification of a novel metabolite in the degradation of pyrene by Mycobacterium sp. strain AP1: actions of the isolate on two- and three-ring polycyclic aromatic hydrocarbons. Appl Environ Microbiol 67(12):5497-5505.

Vilchez-Vargas R, Geffers R, Suárez-Diez M, Conte I, Waliczek A, Kaser VS, Kralova M, Junca H, Pieper DH (2013) Analysis of the microbial gene landscape and transcriptome for aromatic pollutants and alkane degradation using a novel internally calibrated microarray system. Environ Microbiol 15(4):1016-1039.

Watanabe K, Hamamura N (2003) Molecular and physiological approaches to understanding the ecology of pollutant degradation. Curr Opin Biotechnol 14(3):289-295.

Wattam AR, Abraham D, Dalay O, Disz TL, Driscoll T, Gabbard JL, Gillespie JJ, Gough R, Hix D, Kenyon R, Machi D, Mao C, Nordberg EK, Olson R, Overbeek R, Pusch GD, Shukla M, Schulman J, Stevens RL, Sullivan DE, Vonstein V, Warren A, Will R, Wilson MJC, Seung Yoo H, Zhang C, Zhang Y, Sobral BW (2014). PATRIC, the bacterial bioinformatics database and analysis resource. Nucl Acids Res 42 (D1): D581-D59.

Whyte LG, Smits TH, Labbé D, Witholt B, Greer CW, van Beilen JB (2002) Gene cloning and characterization of multiple alkane hydroxylase systems in Rhodococcus strains Q15 and NRRL B-16531. Appl Environ Microbiol 68(12):5933-5942. 
Xu L, Huang H, Wei W, Zhong Y, Tang B, Yuan H, Zhu L, Huang W, Ge M, Yang S, Zheng H, Jiang W, Chen D, Zhao GP, Zhao W (2014) Complete genome sequence and comparative genomic analyses of the vancomycin-producing Amycolatopsis orientalis. BMC Genomics 15:363.

Yang X, Rui Xue, Chong Shen, Shuren Li, Chong Gao, Qi Wang, Xiaoxia Zhao (2011) Genome sequence of Rhodococcus sp. strain R04, a polychlorinated-biphenyl biodegrader. J Bacteriol 193(18):5032-5033.

Zeinali M, Vossoughi M, Ardestani SK (2007) Characterization of a moderate thermophilic Nocardia species able to grow on polycyclic aromatic hydrocarbons. Lett Appl Microbiol $45(6): 622-628$.

Zhang C, Anderson AJ (2012) Polycyclic aromatic hydrocarbon degrading gene islands in five pyrene-degrading Mycobacterium isolates from different geographic locations Can $\mathbf{J}$ Microbiol 58(1):102-111.

Zhang Y, Qin F, Qiao J, Li G, Shen C, Huang T, Hu Z (2012) Draft genome sequence of Rhodococcus sp. strain P14, a biodegrader of high-molecular-weight polycyclic aromatic hydrocarbons. J Bacteriol 194(13):3546.

Zhao K, Guo X, Gong J (2013) A novel benzoate-degrading Rhodococcus strain contains three catA genes with one being transcriptionally active during the growth on benzoate. $\mathrm{J}$ Environ Biol 34(2):401-407. 
Table 1 List of probes associated to the 4 catabolic genes families that were found to be targeted by the microarray in A. tucumanensis DSM 45259.

\begin{tabular}{|c|c|c|c|c|c|}
\hline Probe ID & $\begin{array}{r}\text { Fluore } \\
\text { bac }\end{array}$ & $\begin{array}{l}\text { nce (s } \\
\text { round }\end{array}$ & & $\begin{array}{c}\text { Fold } \\
\text { Change }^{1}\end{array}$ & AromaDeg annotation $^{2}$ \\
\hline ALKB_AJ833983 & 5360 & 6022 & 5757 & 43,634 & \multirow[t]{2}{*}{ Alkane hydroxylase (AlkB) } \\
\hline ALKB_AJ833926 & 2655 & 2781 & 2220 & 21,416 & \\
\hline RHDO_AAD17377 & 1968 & 3694 & 3733 & 20,655 & Benzoate dioxygenase (Bzt) \\
\hline RHDO_AAD03558 & 361 & 772 & 1433 & 6,302 & Phthalate 4,5-dioxygenase (Pht) \\
\hline RHMO_Z36909 & 6173 & 6054 & 5585 & 44,98 & Phenol hydroxylase (PH) \\
\hline
\end{tabular}

${ }^{1}$ Signal corresponding to triplicates with standard deviation shown in Supplementary Table S1. Average (for triplicates) fold change of probe signal compared to background signal in the microarray is shown. ${ }^{2}$ AromaDeg-based annotations obtained when each query sequence from probes targeting catabolic genes for which a positive signal was obtained in the microarray was submitted to web-based AromaDeg resource (Duarte et al. 2014). 
Table 2 List of chemical signatures of key metabolites known to participate in the degradation of alkanes and aromatics in culture and control microcosms.

\begin{tabular}{|c|c|c|c|c|}
\hline & \multicolumn{4}{|c|}{ Abundance (a.u.) ${ }^{1,2}$} \\
\hline & $0 \mathrm{~h}$ & $24 \mathrm{~h}$ & $48 \mathrm{~h}$ & $72 \mathrm{~h}$ \\
\hline$n$-Decanoic acid $^{3}$ & 0 & 2071359 & 2736496 & 4518090 \\
\hline$n$-Tetradecanoic acid 4 & 0 & 2458412 & 3202831 & 4382836 \\
\hline Phthalic acid ${ }^{5}$ & 79095538 & 64001448 & 52624286 & 39758652 \\
\hline Protocatechuic acid 5 & 0 & 0 & 770651 & 1112138 \\
\hline 3-Oxoadipic acid ${ }^{5}$ & 4110 & 26955989 & 40657623 & 25657381 \\
\hline Phenol $^{6}$ & 862601 & 498098 & 196556 & 93768 \\
\hline Catechol $^{6}$ & 165585 & 60114743 & 71964381 & 98848577 \\
\hline Benzoate $^{7}$ & 1874035 & 1376927 & 1106361 & 794551 \\
\hline Catechol $^{7}$ & 532343 & 34588533 & 49513068 & 58615247 \\
\hline
\end{tabular}

${ }^{1}$ Abundance (in arbitrary units) was calculated (in triplicates) as the area of the peak (calculated on the basis of $\mathrm{m} / \mathrm{z}$ and/or standards) of chemicals determined by LC-MS (positive [+] and negative [-] polarities) in cultures containing the selected pollutants. Strain DSM 45259 was cultivated on minimal mineral medium with $n$-decane, phenol, benzoate and phthalate $\left(500 \mathrm{mg} \mathrm{L}^{-1}\right)$ as the sole source of carbon and energy, at $30{ }^{\circ} \mathrm{C}$ and $180 \mathrm{rpm}$ during $72 \mathrm{~h}$. Quantification of the biodegradation was further performed by extraction and target analysis of the substrates by LC-MS. Detailed conditions for cultivation and analytics are given in Materials and Methods section. ${ }^{2}$ Abundance levels for biotic and abiotic controls were considered for background corrections. ${ }^{3}$ Abundance levels of the initial pollutant and degradation intermediates in cultures with $n$-decane. ${ }^{4}$ Abundance levels of the initial pollutant and degradation intermediates in cultures with $n$-tetradecane. ${ }^{5}$ Abundance levels of the initial pollutant and degradation intermediates in cultures with phthalic acid; the presence of small amount of oxoadipic acid may be due to the presence of small amount of cells added at the beginning of the assay (see Materials and Methods section for details). ${ }^{6}$ Abundance levels of the initial pollutant and degradation intermediates in cultures with phenol. ${ }^{7}$ Abundance levels of the initial pollutant and degradation intermediates in cultures with benzoate. 


\section{Figure legends}

Figure 1 Potential alkane and aromatic catabolic abilities of A. tucumanensis DSM 45259 guided by microarray data. Solid lines represent single step reactions while dotted lines represent degradation steps where multiple reactions are involved. Enzyme codes as follows: Alkane hydroxylase (AlkB); Benzoate dioxygenase (Bzt); Phthalate 4,5-dioxygenase (Pht); Phenol hydroxylase (PH). Red color names indicated enzymes encoded by genes targeting probes in the catabolome microarray, whereas those with blue color indicates those whose presence was unambiguously demonstrated by the presence of degradation intermediates (see also molecules in blue color) formed by the action of such enzymes. As shown in Table 2, the presence of $n$-decanoic acid, catechol, protocatechuate and 3-oxoadipate was confirmed by target LC-MS analysis. The degradation of catechol was confirmed by measurement of catechol-2,3-dioxygenase activity. Note: $n$-decane has been used as example of the ability of strain DSM 45259 to degrade alkanes, although cultivation tests and target metabolomics analysis also demonstrated its ability to degrade $n$-tetradecane. 